\title{
燃焼場の壁面熱流束を計測する薄膜抵抗センサに関する研究
}

\author{
中別府 修*1，土屋 智洋*2，中村 優斗*2，長坂 圭輔*2
}

\section{Thin film resistance sensor for wall heat flux measurement in premixed combustion}

\author{
Osamu NAKABEPPU ${ }^{* 1}$, Tomohiro TSUCHIYA ${ }^{* 2}$, Yuto NAKAMURA*2 and Keisuke NAGASAKA*2 \\ ${ }^{*}$ Meiji University, School of Science and Technology \\ 1-1-1 Higasimita, Tama-ku, Kawasaki 214-8571, Japan \\ ${ }^{* 2}$ Meiji University, Graduate School of Science and Technology \\ 1-1-1 Higasimita, Tama-ku, Kawasaki 214-8571, Japan
}

Received 6 March 2016

\begin{abstract}
Heat flux measurement method with thin film resistance sensor in a premixed gas combustion field has been studied to develop an accurate heat flux sensor, and to grasp and improve a heat transfer loss of the engine in SIP (Cross-ministerial Strategic Innovation Promotion Program) innovative combustion technology project. The MEMS technology was introduced to satisfy the requirement of the accurate heat flux measurement with high temporal, spatial and heat flux resolution for a turbulent heat transfer in the engine. The thin film resistance sensors of 250 to 1000 micron scale were fabricated on the $\mathrm{Si}$ substrate, and then a calibration method, measurement characteristics and response to the combustion were studied. Since the heat flux was measured through the surface temperature measurement and the transient heat conduction analysis of the sensor, accurate data and an exact thermal model are required. The heat flux calibration using self-heating showed a good agreement between the excited heat flux of $400 \mathrm{~kW} / \mathrm{m}^{2}$ level and measured one with an error less than $10 \mathrm{~kW} / \mathrm{m}^{2}$ for the wide frequency range from $200 \mathrm{~Hz}$ to $8 \mathrm{kHz}$ by introducing an interfacial thermal resistance in the thermal model. The developed measurement system showed heat flux peak of $250 \mathrm{~kW} / \mathrm{m}^{2}$ level with noise of $10 \mathrm{~kW} / \mathrm{m}^{2}$ level against a butane-air premixed gas combustion in an open chamber. Heat transfer analysis showed that the heat flux trend after the peak can be explained by heat conduction between the burnt gas and the sensor wall. It was also demonstrated that the developed system can measure heat flux down to $10 \mathrm{~kW} / \mathrm{m}^{2}$ and up to $5 \mathrm{kHz}$ frequency range. Good prospect of the heat flux sensor for the engine application was obtained with the sufficient accuracy and the resolutions.
\end{abstract}

Key words : Heat flux measurment, Thin film resistance sensor, Combustion, Engine, MEMS, Transient heat conduction

\section{1. 緒 言}

エネルギ有効利用の観点から，内燃機関の熱効率向上は科学技術の重要な課題である. 内閣府の SIP（戦略的 イノベーション創造プログラム）革新的燃焼技術（内閣府，2014）では，エンジンの最大熱効率 $50 \%$ 目標にし たエンジンの総合的改善研究プロジェクトが進められている．著者らは，このプロジェクト内でエンジン内壁面 からの冷却損失を正確に評価する熱流束計測技術の開発を担当している.

従来，エンジン内壁面の熱流束計測には，同軸型熱電対（榎本他，1984），（LeFeuvre et al., 1969）や薄膜熱電対 （中尾他，2015）を用いる表面温度計測と非定常熱伝導解析による熱流束算出が行われている. しかしながら， 熱電対法では，薄膜熱電対の起電力に関する不確かさ，センサ内部構造を反映した非定常熱伝導解析における熱 抵抗值の不確かさ，センサの個体差や経時変化へ対応できないことが懸念され，正確な熱流束計測法が求められ ている．また，エンジン内の乱流熱伝達特性を調べるには，高い時間分解能，空間分解能を持つセンサが必要で あり, MEMS 技術を用いた隣接複数点の熱流束計測によるエンジン内の乱流熱伝達の把握が求められている.

No.16-00083 [DOI:10.1299/transjsme.16-00083], J-STAGE Advance Publication date : 19 July, 2016

*1 正員，フェロー，明治大学理工学部（干214-8571＼cjkstart神奈川県川崎市多摩区東三田 1-1-1）

*2 学生員, 明治大学大学院理工学研究科

E-mail of corresponding author: onakabep@meiji.ac.jp 


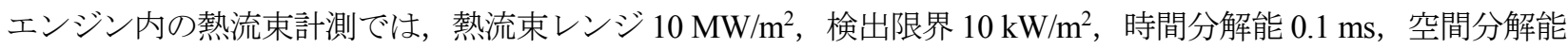
$200 \mu \mathrm{m}$ といった性能レベルが想定される. また, 実機エンジンに設置して使用するために, 動作温度 $200{ }^{\circ} \mathrm{C}$, $20 \mathrm{MPa}$ レベルの圧力変動に耐え, エンジン内壁面へ面一で設置できることがセンサに求められる.

著者らの実施してきた MEMS 研究では, SThM（中別府, 磨田, 2006）やナノカロリメトリ（Ishii and Nakabeppu, 2012）など繊細な微小センサで微量な熱情報を調べる研究が主であったが，本研究はそれらと一線を画し，過酷 環境で高い性能を発揮することが要求される，一足飛びにエンジン設置用のセンサ開発はできず，制作技術の確 立しているシリコン技術をべースにした試作センサから研究を開始した．また，著者らは，MEMS センサを核沸 騰現象へ適用し, 気泡底部の高速, 局所的な熱伝達特性を実験的に明らかにした経験 (Yabuki and Nakabeppu, 2014) があり, エンジン内壁面の熱流束計測も, 壁面温度の高速計測と一次元非定常熱伝導解析により実施することを 着想した.

以上を背景に，従来計測法の不確実な点を排し，エンジン内壁面の詳細な熱伝達特性を調べるため，我々は， 熱流束の較正が可能であること, 乱流熱伝達を解像する分解能を持つこと, エンジン内壁面へ適応可能なことを 条件として，MEMS 技術を用いた新たな壁面熱流束センサおよび計測法の開発を目的とした.

これまで，シリコン基板を用いた薄膜測温抵抗体式の表面温度計測センサを試作し，抵抗体に電流を与えて自 己発熱させ，発熱量と抵抗体温度から熱流束計測システムを較正する方法を開発し，層流予混合燃焼場での表面 温度計測と非定常熱伝導解析による壁面熱流束計測試験を実施してきた. 本論文では, 較正可能な熱流束センサ・ 計測法，試作センサ・計測系の諸特性，燃焼場での熱流束計測試験に関して報告する.

\section{MEMS 抵抗体温度センサと熱流束導出方法}

\section{$2 \cdot 1$ シリコン基板センサと駆動回路}

正確な壁面熱流束計測には，正確な表面温度計測とセンサの正確な伝熱構造を把握する必要があり，センサの 温度校正が容易で, かつ, 外部からの電流供給により既知の発熱を生じさせられる測温抵抗体（RTD, Resistance Temperature Device）式の温度センサを採用した. エンジン実機での計測には，内壁面材質に近い材料でセンサ開 発する予定であるが, MEMS センサの燃焼場への適用は未経験であったため, 制作技術の確立しているシリコン 基板をベースとしたセンサを試作し，予備研究とした.

試作センサを図 1 に示す．熱酸化層（ $\left.\mathrm{SiO}_{2}\right)$ を持つシリコン基板上に，白金薄膜で蛇行する細線の抵抗体を制 作し，その上に $\mathrm{SiO}_{2}$ の保護層を形成している. 制作にはフォトリソグラフィによるパターニング，スパッタとリ フトオフによる膜形成手法を用いた，表 1 には，センサの層構造と各層の内部時定数，熱抵抗を示す．表には， 後述する較正作業で決定した界面熱抵抗も含めている．熱抵抗を見ると，酸化膜の熱伝導率はシリコンに比べ $1 / 100$ 程度であるため, 絶縁層, 保護層が基板層と同程度の熱抵抗を持ち, 界面熱抵抗は全体の $43 \%$ を占め, 較 正作業は必須であることが分かる.

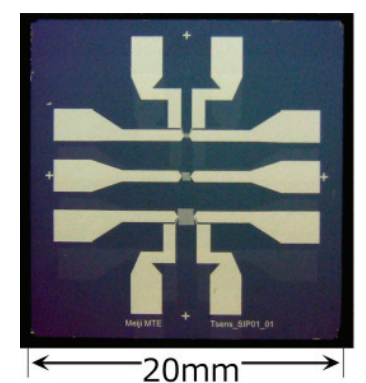

(a)

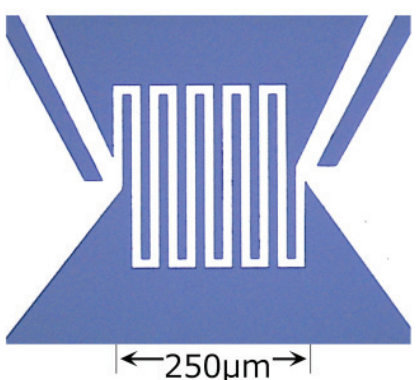

(b)

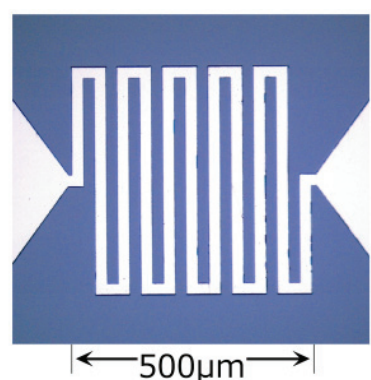

(c)

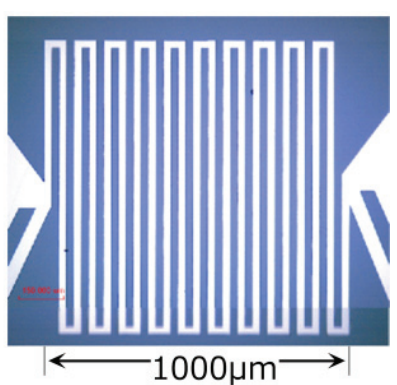

(d)

Fig. 1 (a) Thin film RTD sensor on a Si substrate of $20 \mathrm{~mm}$ scale and $200 \mu \mathrm{m}$ thickness. (b) Type-S of $250 \mu \mathrm{m}$ scale with 4 wire, (c) type-M of $500 \mu \mathrm{m}$ scale of 2 wire and (d) type-L of $1000 \mu \mathrm{m}$ scale with 4 wire. 
センササイズの燃焼場の熱流束計測への影響，一次元非定常熱伝導解析を用いることの妥当性を確かめ，配線 方法の指針を得るため，試作センサには，大きさ 1000 ミクロンの $\mathrm{L} ， 500$ ミクロンの $\mathrm{M} ， 250$ ミクロンの $\mathrm{S}$ のバ リエーションを持たせ, センサ $\mathrm{L}$ と $\mathrm{S}$ は 4 線式, M は 2 線式とした. 3 種の抵抗体の典型的な特性を表 2 に示す. 抵抗温度係数 $\alpha[1 / \mathrm{K}]$ は，センサと温度センサをアルミボックス内に設置し，ボックス温度を上昇・下降させて抵 抗值と温度の関係を調べるボックス法で計測した．結果は， $\alpha=0.00205 \pm 2 \%[1 / \mathrm{K}]$ と白金バルクの值に比べて $50 \%$ 程度となっている，著者らの経験では，理由は不明であるが，酸化シリコン上にクロムバッファ層を介して蒸着

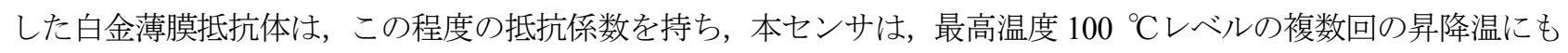
安定した抵抗温度係数を示しており, 実験結果の解析には実測值を使用した.

Table 1 Layer structure of the sensor from top and thermal properties

\begin{tabular}{|l|c|c|c|c|}
\hline \multicolumn{1}{|c|}{ Layer } & $\begin{array}{c}\text { Material } \\
(\text { method })\end{array}$ & $\begin{array}{c}\text { thickness } \\
\mu \mathrm{m}\end{array}$ & $\begin{array}{c}\text { Time const. } \\
\mu \mathrm{s}\end{array}$ & $\begin{array}{c}\text { Thermal resistance } \\
\mathrm{K} /\left(\mathrm{MW} / \mathrm{m}^{2}\right)\end{array}$ \\
\hline Passivation & $\mathrm{SiO}_{2}$ (spatter) & 2 & 6.3 & 1.45 \\
\hline Sensor & $\mathrm{Pt}$ & 0.65 & 0.017 & 0.0091 \\
\hline Interfacial resistance & - & - & 0 & 3.3 \\
\hline Insulation & $\mathrm{SiO}_{2}$ (thermal) & 2 & 6.3 & 1.45 \\
\hline Substrate & $\mathrm{Si}$ & 200 & 507 & 1.53 \\
\hline \hline Total & - & 204.7 & - & 7.74 \\
\hline
\end{tabular}

Table 2 Specifications of typical thin film resistance sensors

\begin{tabular}{|c|c|c|c|c|c|}
\hline Type & $\begin{array}{c}\text { outline size } \\
\mu \mathrm{m}\end{array}$ & $\begin{array}{c}\text { strip / space } \\
\text { width, } \mu \mathrm{m}\end{array}$ & $\begin{array}{c}\text { Resistance } \\
\Omega\end{array}$ & $\begin{array}{c}\text { Temp. coefficient } \\
1 / \mathrm{K} @ 25^{\circ} \mathrm{C}\end{array}$ & $\begin{array}{c}\text { wiring } \\
\text { method }\end{array}$ \\
\hline $\mathrm{S}$ & 250 & 12.5 & 68.4 & 0.00206 & 4 wire \\
\hline $\mathrm{M}$ & 500 & 25 & 78.9 & 0.00209 & 2 wire \\
\hline $\mathrm{L}$ & 1000 & 25 & 279 & 0.00202 & 4 wire \\
\hline
\end{tabular}

センサ駆動回路の模式図を図 2 に示寸. 3 チャンネルの並列計測用回路を自作したが，図には 1 チャンネル分 を示している. センサの駆動には, 定電流回路から $0.5 \sim 2 \mathrm{~mA}$ 程度の電流をセンサに供給し, 温度変化を抵抗体 両端の電位差変化として, 計装アンプを用いたローパスフィルタ付きの 100 倍増幅アンプを通して, 出力する. 計測時のセンサの自己発熱密度は最大 $4.4 \mathrm{~kW} / \mathrm{m}^{2}$, 昇温量は約 $34 \mathrm{mK}$ と微小であり, 計測に影響は与えない. セ ンサ出力は高速 $\mathrm{AD}$ ボードで記録する. センサと駆動回路の配線は，センサ S, L では電流用配線と電圧計測用 配線を分離したセンサ抵抗值を正確に測る 4 線式とし，センサ M では，配線抵抗を含めてセンサ抵抗值を測る 2 線式とした. ここで，一般的なブリッジ回路を採用しなかったのは，高熱流束場で大きな抵抗值変化が生じた際 の非線形性を嫌ったためである. 定電流回路を用いることで, 抵抗体の温度変動 $\Delta T[\mathrm{~K}]$ に対して, 出力電圧 $\Delta V[\mathrm{~V}]$ は, アンプゲイン $G=100$, 電流 $I[\mathrm{~A}]$, 基準抵抗值 $R_{0}[\Omega]$, 温度係数 $\alpha$ を用いて式(1)となり, 線形な計測が可能と なっている. 定電流回路と増幅回路のローパス特性のカットオフ周波数はそれぞれ $12 \mathrm{kHz}, 8 \mathrm{kHz}$ と測定され, 合成特性では $5 \mathrm{kHz}$ のカットオフ周波数となる. $\mathrm{AD}$ ボードのサンプリング周波数は，5 10 kHz とした.

$$
\Delta V=G \cdot i \cdot R_{0} \cdot \alpha \cdot \Delta T
$$

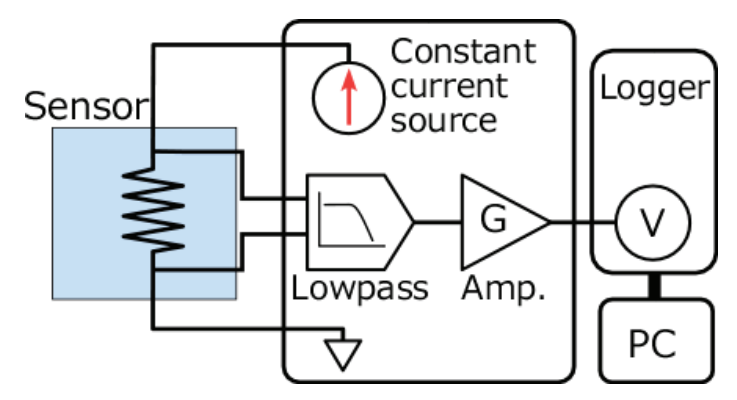

Fig. 2 Schema of driver circuit for thin film resistance sensor. 


\section{$2 \cdot 2$ 熱流束算出方法}

本計測では，センサの表面温度を測り，センサ内の熱伝導解析から熱流束を求める. 熱流束の導出には，セン サの多層構造を反映した伝熱モデルに関して式(2)の 1 次元非定常熱伝導方程式を解く.ここで, 各層の比熱 $c$, 密度 $\rho$, 熱伝導率入には表 1 の構成材料のバルク物性值を使用している.

$$
\frac{\partial \rho c T}{\partial t}=\frac{\partial}{\partial x} \lambda \frac{\partial T}{\partial x}
$$

また，微細加工で制作したセンサでは，膜の形成状態によって伝熱特性が変化し，厚さの設計值，素材の物性 值を用い, 計測された温度変動を与えても, 正しい熱流束が再現されない可能性がある. 本研究では, 後述する 較正過程を通じて，白金抵抗体層と絶縁層の間に界面熱抵抗 $R_{t}\left[\mathrm{~K} /\left(\mathrm{MW} / \mathrm{m}^{2}\right)\right]$ を導入し，センサへの付与熱流束と 計測熱流束との整合を取れるようにした。

抵抗体層最上部の境界条件には，計測温度 $T_{w}(t)$ をちえが，熱流束の交流計測を対象としているため，計測温 度は直流成分を除いた変動成分のみを与える，センサ背面の境界条件は，試験装置上でセンサ基板全体が冷却さ れる熱時定数から, 熱伝達率 $20 \mathrm{~W} / \mathrm{m}^{2} \mathrm{~K}$ と測定したが, 計測対象を周波数 $10 \mathrm{~Hz}$ 以上の熱流束入力とすると, 背面 の熱輸送効果は非定常効果の $0.1 \%$ 以下となるため, 断熱条件を与えた. 数值解法には, コントロールボリュー ム法による離散化と完全陰解法による時間発展を使った.

センサ表面へ流入する熱流束 $q_{w}(t)$ は，熱伝導解析から得た温度分布より，計算領域最上層 $(x=w)$ の白金抵抗 体層内でセンサ内部へ向かう熱流束に抵抗体層上の厚さ $\delta_{p}$ の保護層の顕熱変化を加え, 式(3)より算出する.

$$
q_{w}(t)=-\left.\lambda \frac{d T}{d x}\right|_{w}+\delta_{p} \rho c \frac{d T_{p}}{d t}
$$

\section{$2 \cdot 3$ センサ応答速度の見積り}

抵抗体センサ最上層に正弦波状温度変動を与え, 対応する流入熱流束を一次元非定常熱伝導解析で計算し, 熱 流束と温度の振幅比を変換係数 $\alpha_{T / q}\left[\mathrm{~K} /\left(\mathrm{MW} / \mathrm{m}^{2}\right)\right]$ として図 3 に示した. 背面の境界条件を断熱と, 実測した熱伝達 率 $20 \mathrm{~W} / \mathrm{m}^{2} \mathrm{~K}$ とした場合を示すが, $0.03 \mathrm{~Hz}$ 以上では 2 本の曲線は重なり，実質的にセンサ背面は断熱として扱え ることが再確認できる.

変換係数 $\alpha_{T / q}$ の周波数特性からは, 表面から付与された熱流束に対するセンサ層の温度変化の応答が読み取れ る. まず, 背面に熱伝達率 $20 \mathrm{~W} / \mathrm{m}^{2} \mathrm{~K}$ を与えた場合, $0.01 \mathrm{~Hz}$ 以下ではセンサ全体が周囲環境温度の熱溜に熱抵抗 で繋がれた状態となり, 定常的に振舞う棚が見られる. $0.01 \mathrm{~Hz}$ から $200 \mathrm{~Hz}$ までは, 傾き -1 乗の右下がりの特 性を示し, 付与熱流束に応じて基板全体の温度が変動する準断熱状態となる. 背面断熱条件ではこの特性が無限

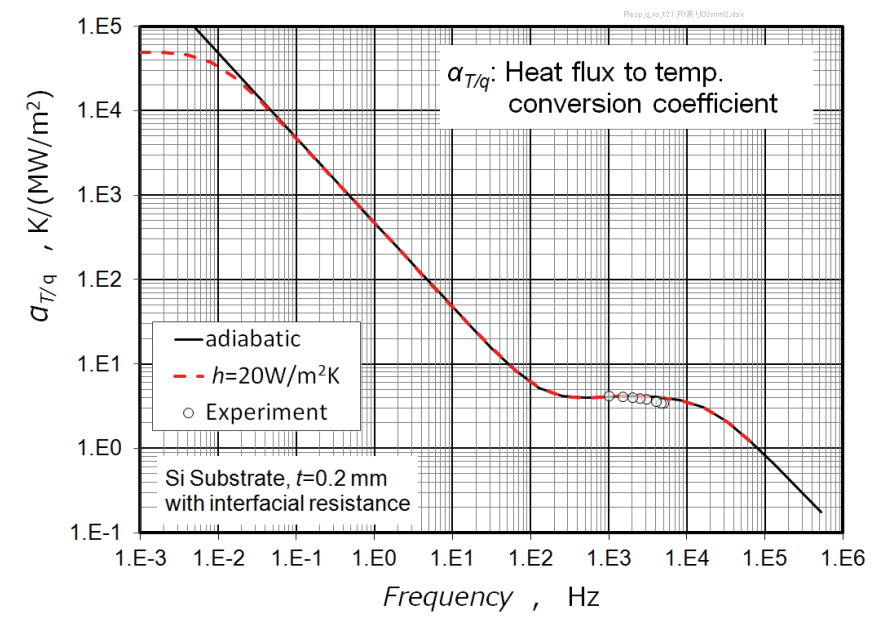

Fig. 3 Frequency characteristics of heat flux to surface temperature conversion coefficient. 
に低周波数側へ続くことになる. $200 \mathrm{~Hz}$ から $10 \mathrm{kHz}$ の間では，センサ層は絶縁層の熱抵抗と界面熱抵抗を介し て熱溜となるシリコン基板に繋がれた状態となり，再び定常的な振舞いを示寸棚が見られる. $10 \mathrm{kHz}$ 以上の高周 波数領域では, 絶縁層上のセンサ層, 保護層は準断熱状態となり, 変換係数は再び周波数に反比例する.

変換係数の絶対值に関しては, $10 \mathrm{kHz}$ 信号に対して $\alpha_{T / q}=3.3 \mathrm{~K} /\left(\mathrm{MW} / \mathrm{m}^{2}\right)$ となっている.これは，検出限界に想 定している $10 \mathrm{~kW} / \mathrm{m}^{2}$ の熱流束入力に対して, 温度変動が $0.033 \mathrm{~K}$ となり, 計測でこの温度を測り取る必要がある. 後述する燃焼場の熱流束計測実験の結果の分析 (図 11) から, センサ $\mathrm{S}$ の変換係数はモデルと良く一致しており, 温度信号のノイズは標準偏差で 0.02 0.05 K 程度（@帯域幅 $5 \mathrm{kHz}$ ）となっている. 好調な条件で計測できれば目 標達成の見込みがある。

\section{3. 自己発熱を用いた熱流束較正}

従来の熱電対を用いた表面温度計測・熱伝導解析方式の熱流束計測では，既知の熱流束をセンサに与えること が難しく，較正が困難である．本研究で提案する抵抗体温度センサ方式では，外部から抵抗体に電流を流し，正 確な量の発熱を与えることができ, 付与熱流束と温度変化から算出された計測熱流束を比較し, 解析モデルへ必 要な修正を施すことができる（中別府，2015）.

図 4 に較正過程のフローチャートを, 図 5 に較正作業時の装置図を示す，較正作業では，まず，ファンクショ ンジェネレータからパワーアンプを介して変動電流をセンサに印加し周期的な発熱をセンサの抵抗体で発生させ, センサの抵抗体にかかる電圧 $V(t)$ とシャント抵抗にかかる電圧から電流 $I(t)$ を記録する. 付与熱流束の変動成分 $q_{\text {exc }}(t)$ は総発熱から定常発熱分を除き，抵抗体面積を $A$ として式(4)で求められる. 同時にセンサの抵抗值の変動 成分 $\tilde{R}(t)$ から式(5)より，温度変化 $T_{\text {meas }}(t)$ を求める，ここで $\bar{V}, \bar{I}$ は電圧，電流の定常成分である.

$$
\begin{aligned}
& q_{\text {exc. }}(t)=\frac{V(t) \times I(t)}{A}-\frac{\bar{V} \times \bar{I}}{A} \\
& T_{\text {meas. }}(t)=\frac{\tilde{R}(t)}{R_{0} \times \alpha}=\frac{V(t) / I(t)-\bar{V} / \bar{I}}{R_{0} \times \alpha}
\end{aligned}
$$

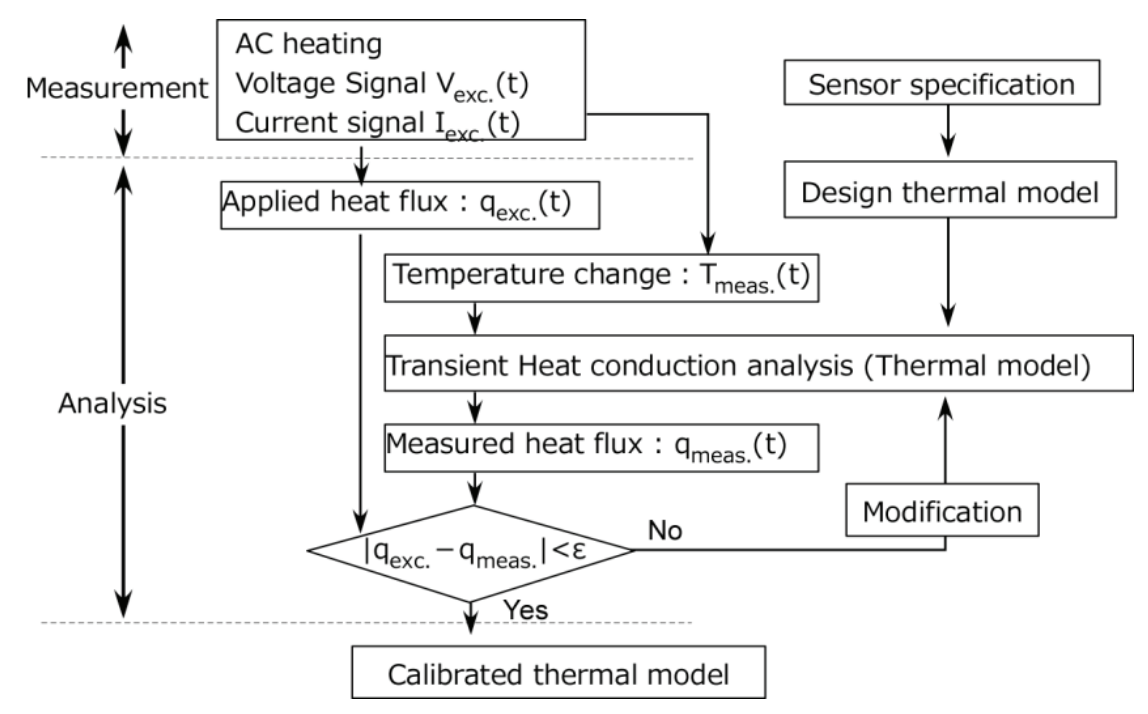

Fig. 4 Flow chart of the calibration process with self-heating. 


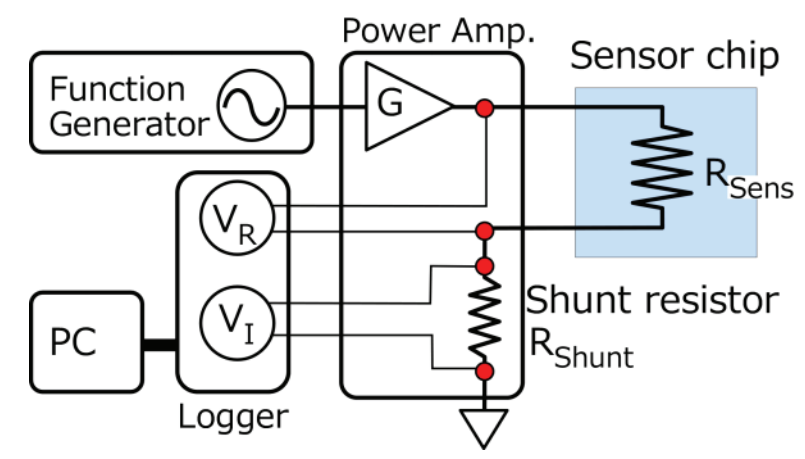

Fig. 5 Schema of self-heating and resistance measuring circuit for the heat flux calibration process.

次に, 温度データ $T_{\text {meas }}(t)$ をセサ表面の境界条件として 2 章の熱伝導解析を行い, 計測熱流束 $q_{\text {meas }}(t)$ を求め, 付与熱流束 $q_{\text {exc }}(t)$ と比較する. 両熱流束が一致しない場合, 伝熱モデルの界面熱抵抗を調整し, 計測熱流束を付 与熱流束に一致させる．ここで，調整手段として構造モデル，物性值の修正も可能であるが，調整の自由度を増 やすと煩雑さを増すため，金属薄膜抵抗層と絶縁層の間に界面熱抵抗を設定することとした．この修正方法に明 確な根拠はないが, 著者らの微細加工によるセンサ制作の経験から試行錯誤的に決定した.この較正作業の結果, 当該センサに対して界面熱抵抗を含めた較正済みの解析モデルが得られることとなる.

図 6 にセンサ L の抵抗体に周波数 $2 \mathrm{kHz}$ の正弦波状発熱を与えた場合の較正過程の様子を示寸．振幅約 350 $\mathrm{kW} / \mathrm{m}^{2}$ の付与熱流束変動に対して, 計測したセンサ温度信号を与え, 白金薄膜と絶縁層の間の界面熱抵抗を $R_{t}=1$, $2,3.3 \mathrm{~K} /\left(\mathrm{MW} / \mathrm{m}^{2}\right)$ と変えて算出した熱流束を示している. $R_{t}=3.3 \mathrm{~K} /\left(\mathrm{MW} / \mathrm{m}^{2}\right)$ とすることで, 付与熱流束と算出熱流 束は良く一致している，逆に見ると，較正しない場合，本計測手法は極端に正確性の低い計測結果を与える可能 性が示されている.

図 7 に周波数 $1 \mathrm{kHz}, 8 \mathrm{kHz}$ の熱流束を与えた場合の較正結果を示す. 温度計測ノイズによる熱流束のノイズ成 分を除くと, いずれも $R_{t}=3.3 \mathrm{~K} /\left(\mathrm{MW} / \mathrm{m}^{2}\right)$ の界面熱抵抗により, 付与熱流束と計測熱流束が誤差 $10 \mathrm{~kW} / \mathrm{m}^{2}$ 以下で 一致している. 同様の作業は $200 \mathrm{~Hz} \sim 20 \mathrm{kHz}$ まで実施したが, $10 \mathrm{kHz}$ 以上では温度計測に高調波成分が現れ良い 一致は得られなかったが，200 Hz 8 kHzでは同一の界面熱抵抗值によって較正が実施できた.

これより, 抵抗体式センサを外部から自己発熱させて, その結果を用いて解析モデルを修正し, 正しい熱流束 を算出する壁面熱流束計測システムが実証された．また，この結果は，センサをエンジンへ設置した状態で計測 システムを較正できるメリットが得られることを示している.

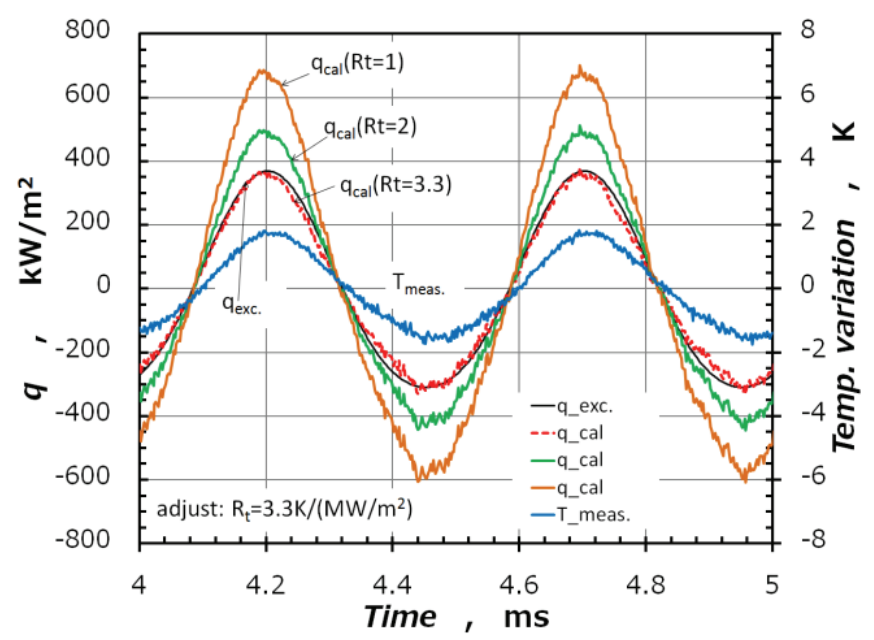

Fig. 6 Adjustment of measured heat flux to excited heat flux by changing interfacial thermal resistance for heat input at $2 \mathrm{kHz}$. 


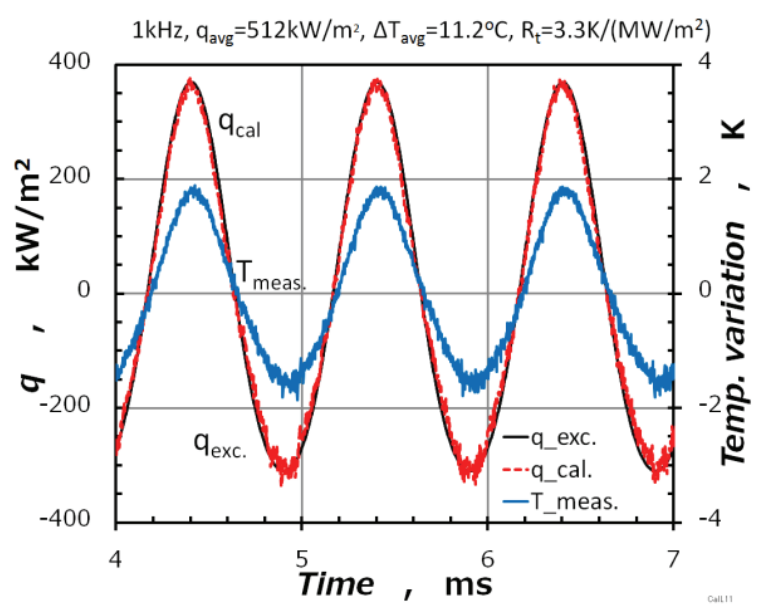

(a)

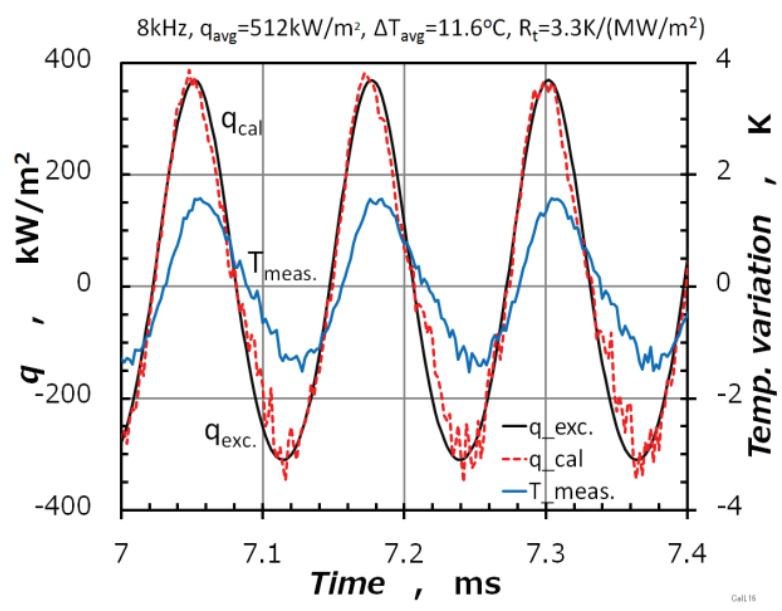

(b)

Fig. 7 Heat flux calibration with sinusoidal self-heating at (a) $1000 \mathrm{~Hz}$ and (b) $8000 \mathrm{~Hz}$.

\section{4. 燃焼場の熱流束計測実験}

\section{$4 \cdot 1$ 実験装置·条件}

試作センサの燃焼場への適用性を調べるために，ブタンと空気の予混合ガスを用いた層流燃焼に対する壁面熱

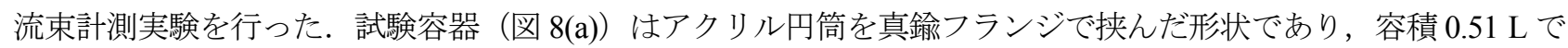
ある. 安全性の観点から上部フランジに開口を設け，シリコンゴムシートで簡易的に閉じ，内圧がかかると自動 的に開く開放型とした，容器内部にはファンを設置し，所定の量の燃料ガスを注入後に回転させ，均一な予混合

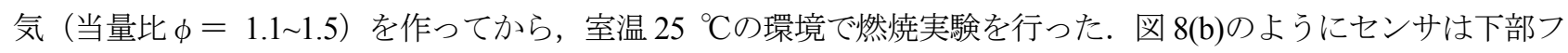
ランジ中央に設置し，センサの上部 $3.4 \mathrm{~mm}$ に線径 $25 \mu \mathrm{m}$ の Pt-PtRh13\%熱電対を配置した.

点火は，容器側壁へ取り付けた 2 輪車用プラグでのイグナイタ一の放電で実施した．放電電圧をトリガー信号 として，熱電対信号，センサ信号を高速 $\mathrm{AD}$ ボードで記録し，自発光の様子はハイスピードカメラで 1000FPS の 速度で撮影した．図 8(c)は容器内を球状に伝搬する火炎の写真である. 実験時には，上部フランジの開口から外 部へ燃焼ガスが噴出し，底部の反応帯がセンサ面へ伝搬する燃焼形態を示した。

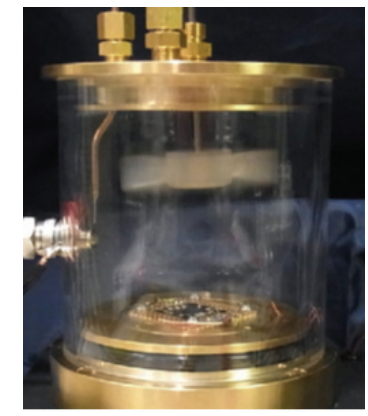

(a)

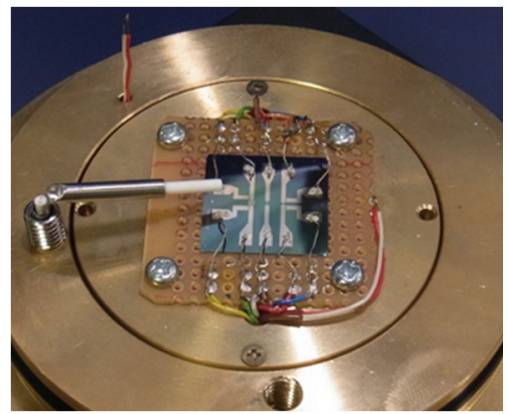

(b)

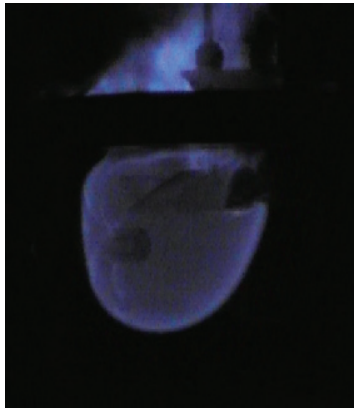

(c)

Fig. 8 (a) Open chamber for premixed combustion test. (b) Sensor on a bottom flange and TC set above the sensor. (c) Snap shot of self-emitting light of butane-air premixed gas flame.

\section{$4 \cdot 2$ 実験結果}

図 9 は火炎の自発光の連続スナップショットであり, 平滑な球凯状の反応帯が底部のセンサ面へ伝播する様子 を示している．70 75 ms の間に火炎はセンサ面へ到達している. 75，80，85 ms の写真には右上がりの発光線が 見られるが，反応帯にセル状の不安定が現れ始めているものと考えられる. また, 反応帯の伝播速度はブタンの 燃焼速度よりも早く, 流れに乗って進行しており, 火炎が底面に到達後の変動の様子からは燃焼に伴い内部に流 れが発生していることが観察されている. 
図 10 は同時に計測されたガス温度，センサ S で測定した壁面温度と算出された熱流束である．素線径 25 ミク ロンの熱電対で計測したガス温度には，非定常性，熱伝導，ふく射の補正（水谷，2002）を行った．補正では非 定常性の補正効果が最も大きいが，燃焼場中での熱電対の時定数が不明のため，実験全体を通じて最高温度が断 熱火炎温度レベルとなるように時定数を $10 \mathrm{~ms}$ と定めた．よって，補正ガス温度は推定を含む参考值である.

補正ガス温度からは, 反応帯が熱電対を通過すると最高温度レベルに達し, 数 $\mathrm{ms}$ 寸ると低下し始め, $30 \mathrm{~ms}$ 程度で計測温度と補正温度が同じレベルになっている，既燃ガス温度は，壁面で泠却される影響と温度斑のある 流体塊がセンサ部に流れてくる影響を含み，例えば，時刻 $135 \mathrm{~ms}$ に見られる温度トレンドの変化のように，単調 でない変化も記録されている.

センサの計測温度は，火炎が壁面に到達すると $2 \mathrm{~K}$ 程度急上昇し，その後，傾きを緩めながら上昇していく。 図 10 では熱流束がほぼ 0 レベルとなる火炎到達後の $200 \mathrm{~ms}$ でも壁温上昇量は $9.5 \mathrm{~K}$ 程度である.気相側には 1900 $\mathrm{K}$ 程度の温度差があることを考えると，センサの温度変化はわずかであり，この系の律速要因は気相側にあるこ とが分かる．壁面温度データを境界条件として熱伝導解析を実施して得られた熱流束は，火炎の到達により急上 昇し， $320 \mathrm{~kW} / \mathrm{m}^{2}$ のピークをとって急速に減衰する挙動を示している。この例では, 熱流束は火炎の到達から約 $70 \mathrm{~ms}$ 後には 0 レベルへ低下している.

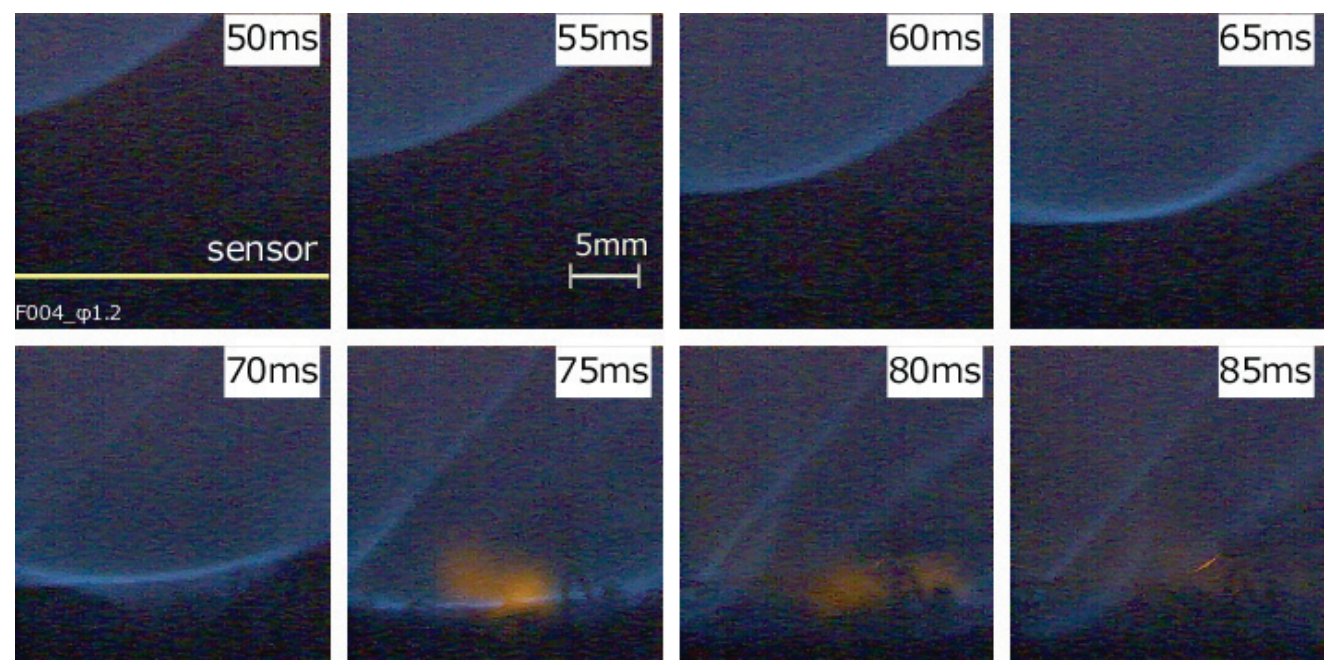

Fig. 9 Propagation of laminar flame to the sensor in premixed gas of butane and air at equivalent ratio of 1.2.

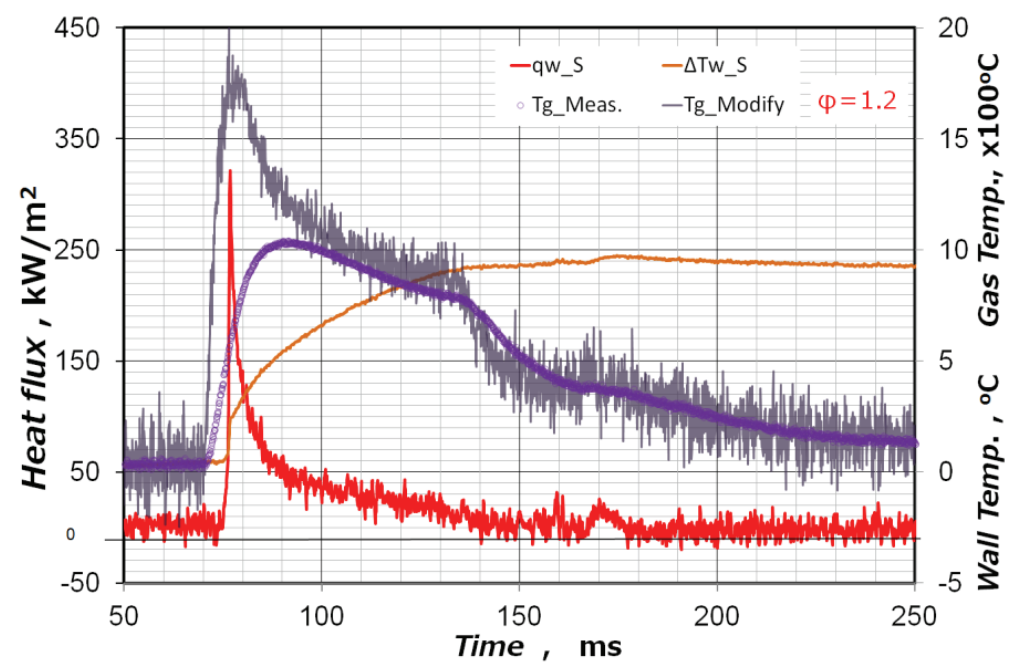

Fig. 10 Gas temperature, wall temperature and heat flux by sensor $\mathrm{S}$ in the premixed combustion of butane-air at equivalent ratio of $\phi=1.2$. 


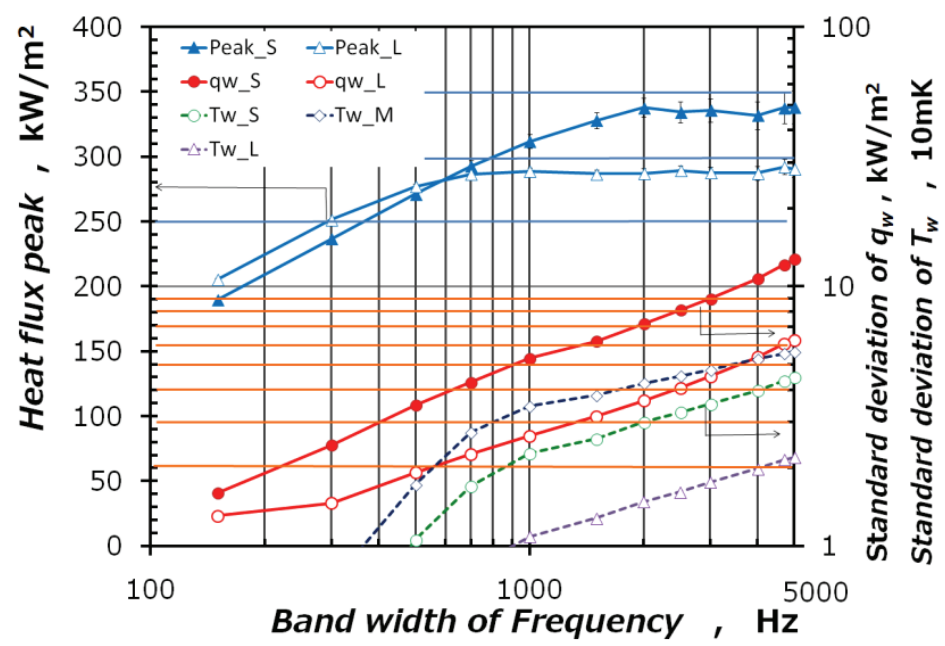

Fig. 11 Reconstruction of the heat flux peak and standard deviation of the heat flux noise and temperature noise of the sensors with digital low-pass filtering via FFT.

図 10 の熱流束波形（センサ S)，および同時にセンサ L で計測した熱流束波形を FFT でスペクトルに分解し， 高周波数成分を除去し，逆 FFTにより波形を再構成するデジタルローパスフィルタを用い，スペクトルの帯域幅 と熱流束のピーク值，熱流束ノイズの標準偏差の関係を調べた（図 11）。また，センサ S，M，L の温度信号から $500 \mathrm{~Hz}$ 以下の低周波数成分を除き，高周波成分に含まれるノイズの標準偏差を同样に FFT 解析で調べた. 結果と して，まず，熱流束ピーク高さはセンサ $\mathrm{L} て ゙ ~ 1 \mathrm{kHz}, \mathrm{S}$ で $2 \mathrm{kHz}$ 以下のスペクトル成分を合成することで再現でき ることが分る. センサ L は面積が S の 4 倍あり, 空間平均が取られている可能性がある. 予混合燃焼場で壁面が 受ける熱流束は高くても $2 \mathrm{kHz}$ 程度までの周波数成分で構成されており, 計測系は $5 \mathrm{kHz}$ までの計測が可能なた め, 十分な速度で計測していると評価される。

熱流束ノイズの標準偏差は $5 \mathrm{kHz}$ までの全帯域データではセンサ $\mathrm{S}$ が $13 \mathrm{~kW} / \mathrm{m}^{2}$ レベル， L が $6.2 \mathrm{~kW} / \mathrm{m}^{2}$ レベル であり, 帯域幅を下げるに従い, 0.5 乗で低下し, ホワイトノイズの特徵を示している.また, 温度信号のノイズ も帯域幅の 0.5 乗にほぼ比例し, 全帯域データでは, センサ L の温度ノイズの標準偏差が $0.022 \mathrm{~K}, \mathrm{~S}$ が $0.045 \mathrm{~K}$, $\mathrm{M}$ が $0.056 \mathrm{~K}$ となった. センサ $\mathrm{M}$ は後に駆動回路の内部ノイズが大きいことが確認されており, 適切な駆動回路 を使用すれば標準偏差 $0.02 \mathrm{~K}$ 程度の温度ノイズ， $6 \mathrm{~kW} / \mathrm{m}^{2}$ レベルの熱流束ノイズで計測できることが示された. また, センサ S, L の熱流束と温度のノイズの標潐偏差から $1 \mathrm{kHz} 5 \mathrm{kHz}$ の範囲の変換係数は $\alpha_{T / q}=3.5 \sim 4 \mathrm{~K} /\left(\mathrm{MW} / \mathrm{m}^{2}\right)$ となり，図 3 のモデル計算と同レベルであることも確認できる.

図 12 には，当量比 $\phi=1.2$ の条件で得られた $2 つ の$ 実験結果を示す．同様の実験操作を実施しているが，(a)の 結果はガス温度の上昇速度が遅く, 上昇開始から $15 \mathrm{~ms}$ 程度で最高温度レベルに達し, 熱流束ピークは低めに得 られた. (b)では, ガス温度は $8 \mathrm{~ms}$ 程度で最高温度レベルに達し, 熱流束ピークは(a)より高く, ややピークが鋭 く見える. サイズ，配線方法を変えた S，M，Lの3センサの計測特性の違いに関しては，図 11 に示すノイズレ ベルの違いはあるが同等の熱流束計測が示されており，本実験では決定的な優劣は見当たらなかった，ただし， エンジン内壁面の熱流束計測にはサブミリスケールの乱流熱伝達計測が求められており, 今回センサ $\mathrm{S}$ で他のセ ンサと同等に熱流束が計測できたことは一つの成果である．また，2 端子法のセンサ M が 4 端子法の S， L と同 等の結果を示したことは，今後のセンサ開発でも簡便な 2 端子法が有効なことを示す成果と考えられる.

図 13 には, 当量比 $\phi=1.3$ および 1.5 の結果を示す. 図 13(a)では, プラグ位置をその他の実験と 180 度変え, 火炎がセンサ L， M， S の順に伝搬した時のものである．熱流束波形はノイズが大きく見えているが，顕著に異 なる特徴はない. (b)では, 熱流束ピークが近い時間に集まっている, これは, 火炎帯がセンサ面に平行に近い形 で伝搬したためと考えられる，断熱火炎温度からは，当量比が大きくなると火炎温度が低下し，熱流束にもその 傾向が表れることを予想したが，図 12，13 の結果からは，法則性は見いだせず，実験回ごとのばらつきが大きい 印象である. 


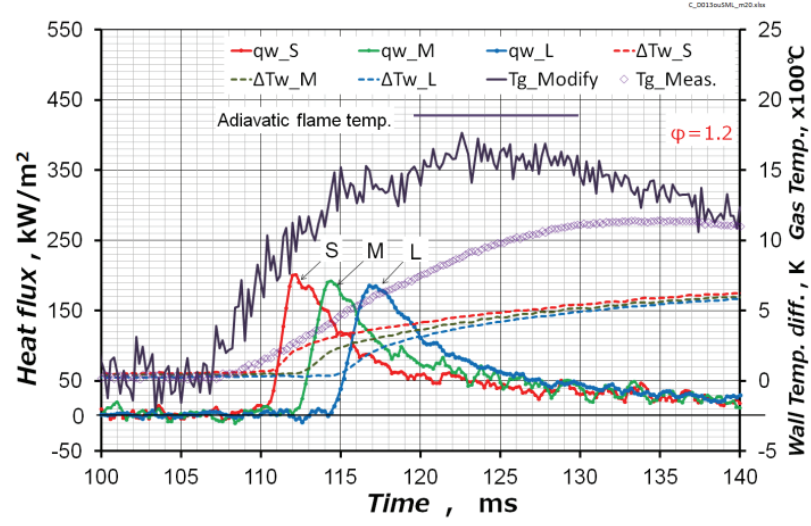

(a)

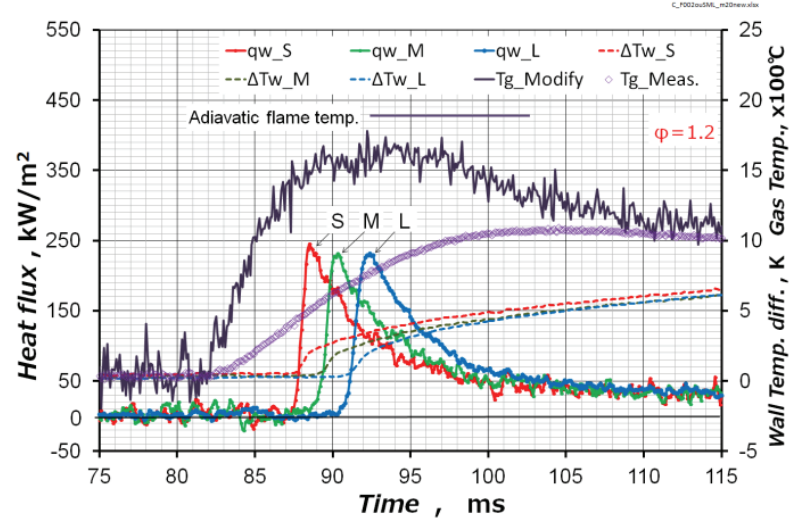

(b)

Fig. 12 Examples of wall heat flux measurement by the sensor S, M, L in the premixed combustion at $\phi=1.2$.

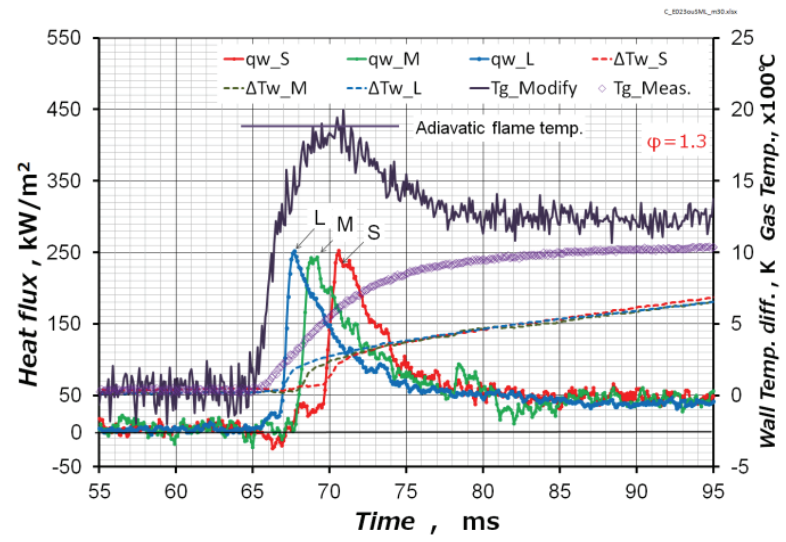

(a)

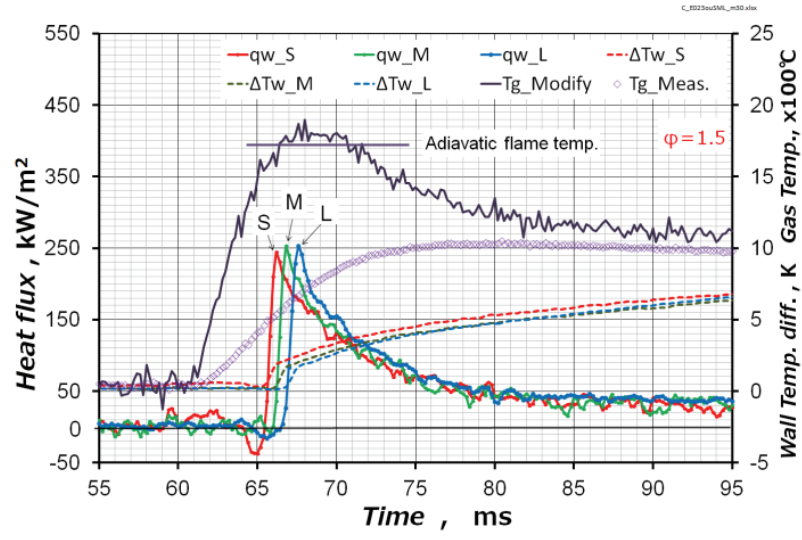

(b)

Fig. 13 Heat flux measurement in the premixed combustion at $\phi=1.3(\mathrm{a})$ and $\phi=1.5(\mathrm{~b})$.

\section{5. 既燃ガスとセンサの熱伝達解析}

\section{$5 \cdot 1$ 解析モデル}

燃焼実験で得られた熱流束の検証を目的に，既燃ガスがセンサに低温ガス層を介して接触する系の一次元非定 常熱伝達解析を行った。炎の接触後の $10 \mathrm{~ms}$ 程度の短い時間であれば流れの影響は小さいと考え, 系の圧力 $p$ を一定とし運動方程式を解かず，熱伝導現象を主とする簡単化を行った．また，火炎の壁面への伝搬では，反応 帯が到達する前に熱伝達が生じ，ガス温度が低下し消炎が起こるが，化学反応も解析に含めていないため，既然 ガスとセンサ表面の間に所定の厚さの低温ガス層があるとモデル化し，消炎効果を表現した．既燃ガスの物性值 には, 当量比 1.2 のブタン・空気予混合気の断熱火炎温度 $(2200 \mathrm{~K})$ において計算される既燃ガスの物性値 (Gordon and McBride, 1996) を持ち, 物性值の温度依存性には空気の特性を用いて近似した物性值 (日本熱物性学会, 2008) を使用した，解析では，気相側温度は $2200 \mathrm{~K}$ から $300 \mathrm{~K}$ 程度まで変化するため, 密度, 比熱, 熱伝導率は温度の 関数とし，特に密度変化は，気相中に流れを生じることになるため，連続の式とエネルギ式では，密度変化に伴 う流れの効果を移流項として含めた，以上より，気相側の支配方程式は以下の 3 式となる.

$$
\begin{aligned}
& \frac{\partial \rho}{\partial t}+\frac{\partial \rho u}{\partial x}=0 \\
& p=p_{0} \\
& \frac{\partial \rho c T}{\partial t}+\frac{\partial \rho c u T}{\partial x}=\frac{\partial}{\partial x} \lambda \frac{\partial T}{\partial x}
\end{aligned}
$$


センサ側は，2 章の伝熱モデルに対して非定常熱伝導方程式を解いた．固体側の温度変化は小さいため各物性 值は一定とした．方程式の離散化にはコントロールボリューム法を用い，移流項には風上法，時間発展には完全 陰解法を適用し，数值計算を行った. 初期条件は既燃ガス層を断熱火炎温度の $2200 \mathrm{~K}$ とし，センサおよびセンサ に接する低温ガス層は $300 \mathrm{~K}$ とした. 既燃ガス側境界条件は断熱火炎温度を与え, センサ背面には断熱条件を与 えた，数值計算では，既然ガス層，低温ガス層，固体層は同時に解いているため界面の境界条件は陽に現れない が，各界面では温度の一致と熱流束の連続が保たれている.

\section{$5 \cdot 2$ 解析結果}

図 14 にセンサへ流入する熱流束を示す．低温ガス層厚さを $\delta_{y}=40 ， 80 ， 100 ， 120$ ミクロンとした計算結果と 当量比 1.2 の実験結果 2 例を示している. 挿入図は解析場の温度分布の変化を模式的に示している. 解析結果は, 時刻 $0 \mathrm{~ms}$ から熱流束が立ち上がり, ピーク值は低温ガス層厚さが薄いほど高く, ピーク後の減衰は $3 \mathrm{~ms}$ 以降で は低温ガス層の影響は見られない。この減衰挙動は時間の-0.5 乗に比例しており，この系の熱伝達が気相側の熱 伝導支配であることを示している. 実験結果はピーク位置が概ね解析結果のピークと一致するよう時刻をずらし て示しているが，ピーク時刻の $1 \mathrm{~ms}$ 程度前から熱流束が立ち上がっており，火炎の伝搬に伴う壁面への伝熱がモ デルよりも早く影響しており，ここで実施した簡易解析では表現できない立ち上がり方をしている．実験のピー ク值は解析で低温ガス層を 80 110 $\mu \mathrm{m}$ 程度に仮定したものと一致し, $1 \mathrm{~ms}$ 以降では減衰挙動は解析結果と良く一 致している.この減衰挙動の一致は時刻 $10 \mathrm{~ms}$ 程度まで見られ，図示してないが，それ以降は実験の熱流束が早 く減衰しており, 容器内部で生じる燃焼ガスの膨張, 流出, 反動としての流入に伴う流れが影響しているものと 考えられる.

解析は流れを解かない簡易なものであり，火炎の到達に伴う熱流束の立ち上がりは再現できなかったが，ピー クをとってから時間の約一 0.5 乗で減衰する熱流束挙動は, 気相側の熱伝導に支配され, 既燃ガスの非定常熱伝導 により説明できることが示された。これより，試作センサの測った熱流束は燃焼場での壁面熱流束として大きな 誤りはなく, 妥当なものと考えられる.

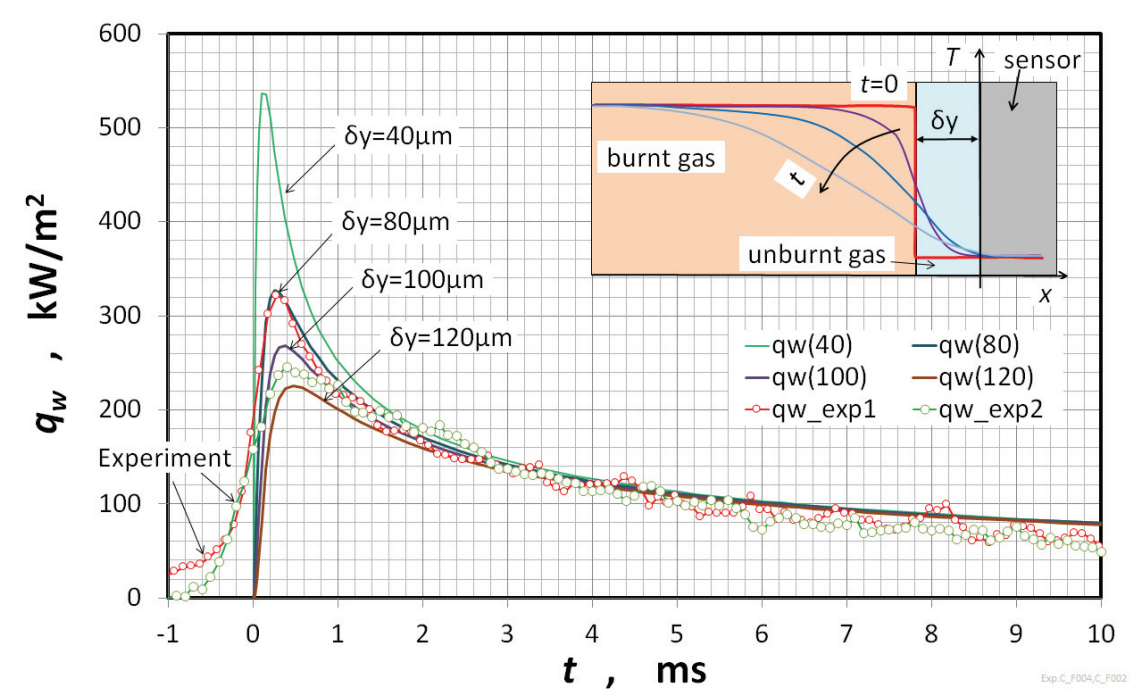

Fig. 14 Heat flux peaks simulated by heat conduction model with advection of heat. Unburnt gas layer is assumed on the sensor for expressing extinction of premixed gas flame.

\section{6. 結 論}

エンジン内壁面の熱流束計測センサの開発に向けて, 薄膜抵抗体温度センサを MEMS 技術で試作し, 熱流束較 正方法，計測特性を調べ，燃焼場での熱流束計測実験を実施した。 
・提案した薄膜抵抗体式センサでは，自己発熱に対する温度変化から熱流束を算出し，センサ内の伝熱モデル を修正する較正法により，熱流束計測の定量性を得られることを示した。

・試作センサ，駆動回路の周波数特性から， $5 \mathrm{kHz}$ までの周波数範囲で, 表面温度 $0.02 \mathrm{~K} レ$ レルからの計測が 実証され, $10 \mathrm{~kW} / \mathrm{m}^{2}$ レベルからの熱流束計測が可能と見積もった.

・静止予混合気中を火炎が伝播しセンサ面に到達する燃焼場の熱流束計測試験では, 火炎の伝播後 $1 \mathrm{~ms}$ 程度で 熱流束が急速に立ち上がり, $250 \mathrm{~kW} / \mathrm{m}^{2}$ レベルの最大值をとり, 7 8 $\mathrm{ms}$ の時定数で減衰するピークが計測された. また, 熱流束計測のノイズは適切な回路の使用で $6 \mathrm{~kW} / \mathrm{m}^{2}$ レベルに抑えることが可能であり, サイズ 250 ミクロ ンのセンサ，2端子法による配線でも支障無く計測可能なことが示された.

・燃焼場の熱流束ピークの減衰挙動は, 既燃ガスとセンサが非然ガス層を介して接触すると仮定した非定常熱 伝導モデルにより説明できることが示された．火炎の伝播に伴う壁面の予熱効果や消炎効果は未検討であり，熱 流束ピーク值の説明はできていないが, 提案するセンサおよび計測法は, 燃焼場の熱流束計測に大きな誤りを含 んではおらず, 妥当なものと考えられる.

\section{謝 辞}

本研究は, SIP (戦略的イノベーション創造プログラム) 革新的燃焼技術に関する研究として実施したものであ る.また，センサ制作には東京工業大学メカノマイクロプロセス室を利用した．関係各位に謝意を表す。

\section{文献}

内閣府，SIP（戦略的イノベーション創造プログラム） (online), available from $<\mathrm{http}: / / \mathrm{www} 8 . c a 0 . g o . j p / c s t p / g a i y o / s i p / i n d e x . h t m l>(2014)$, (参照日 2016 年 3 月 1 日).

榎本良輝，古浜庄一，水上浩，四サイクルガソリン機関の燃焼室壁への直接熱損失（第 1 報, ピストンおよびシ リンダライナへの熱損失)，日本機械学会論文集 B 編，Vol. 50, No. 456 (1984), pp.1972-1980.

Gordon, S. and McBride, B. J., Computer program for calculation of complex chemical equilibrium compositions and applications, NASA Reference Publication 1311 (1996). available from

$<\mathrm{http}: / /$ www.grc.nasa.gov/WWW/CEAWeb/ceaHome.htm> (参照日 2016 年 3 月 1 日).

Ishii, J. and Nakabeppu, O., Nanocalorimeter for DTA and mass measurement in high temperature range, Netsu Sokutei W39 (2012), pp.14-19.

日本熱物性学会編, 新編 熱物性ハンドブック(2008), pp. 198-202, 養賢堂.

LeFeuvre, T., Myers, P. S. and Uyehara, O. A., Experimental instantaneous heat fluxes in a diesel engine and their correlation, Society of Automotive Engineers Trans., Vol. 78, SAE paper 690464 (1969), pp.1717-1738.

水谷幸夫，燃焼工学第 3 版 (2002), pp.239-241, 森北出版.

中別府修，磨田謙一，SThMによる局所熱伝導率計測に関する研究，日本機械学会論文集 B編，Vol. 72, No. 722 (2006), pp.2524-2531.

中別府修, 熱流束センサおよびその較正方法, 被測定物の異常検知方法並びにエンジンの動作異常検知方法, 特 願 2015-209118（2015）。

中尾 裕典, 青木 理, 清末 涼,原田 雄司, 角島 信司, 小池 祐輔, 高応答遮熱壁面における瞬時熱流束計測技術, マツダ技報, No.32 (2015), pp. 222 227.

Yabuki, T. and Nakabeppu, O., Heat transfer mechanisms in isolated bubble boiling of water observed with mems sensor, International Journal of Heat and Mass Transfer, Vol. 76 (2014) pp. 286-297.

\section{References}

Cabinet office, Government of Japan, Cross-ministerial Strategic Innovation Promotion Program (SIP), (online) available from $<$ http://www8.cao.go.jp/cstp/gaiyo/sip/index.html $>$ (2014), (accessed on 1 March, 2016).

Enomoto, Y., Furuhama, S. and Mizukami, H., Direct heat loss to combustion chamber of four cycle gasoline engine $\left(1^{\text {st }}\right.$ report, Heat loss to piston and cylinder liner), Transactions of the Japan Society of Mechanical Engineers, Series B, Vol. 50, No. 456 (1984), pp.1972-1980 (in Japanese).

Gordon, S. and, McBride, B. J., Computer program for calculation of complex chemical equilibrium compositions and applications, NASA Reference Publication 1311 (1996). (online) available from 
$<$ http://www.grc.nasa.gov/WWW/CEAWeb/ceaHome.htm> (accessed on 1 March, 2016).

Ishii, J. and Nakabeppu, O., Nanocalorimeter for DTA and mass measurement in high temperature range, Netsu Sokutei W39 (2012), pp.14-19.

Japan Society of Thermophysical Properties ed., Handbook of Thermal Properties, pp.198-202 (2008), Yokendo co. (in Japanese).

LeFeuvre, T., Myers, P. S. and Uyehara, O. A., Experimental instantaneous heat fluxes in a diesel engine and their correlation, Society of Automotive Engineers Trans., Vol. 78, SAE paper 690464 (1969), pp.1717-1738.

Mizutani, Y., Combustion Engineering $3^{\text {rd }}$ edition (2002), pp.239-241, Morikita Publishing co. (in Japanese).

Nakabeppu, O. and Tokita, K., Study on local thermal conductivity with SThM, Transactions of the Japan Society of Mechanical Engineers, Series B, Vol. 72, No. 722 (2006), pp.2524-2531 (in Japanese).

Nakabeppu, O., Heat flux sensor and its calibration method, anomaly detection method of object and engine, Japanese Patent Application, No. 2015-209118 (2015) (in Japanese).

Nakao, Y., Aoki, O., Kiyosue, R., Harada, Y., Kadoshima, S. and Koike, Y., Technology of Instantaneous heat flux measurement on a high response heat insulation coating, Matsuda Technical Review, No.32 (2015), pp. 222-227 (in Japanese).

Yabuki, T. and Nakabeppu, O., Heat transfer mechanisms in isolated bubble boiling of water observed with MEMS sensor, International Journal of Heat and Mass Transfer, Vol. 76 (2014), pp. 286-297. 